ослідження конфліктів є новим н уковим н прямом у суспільній геогр фії, що потребує вироблення оригін льної методологічної б зи. м г ння держ ви щодо досягнення вищого геополітичного ст тусу - 3 кономірний процес, результ том якого $є$ ієр рхіз ція політико-територі льної структури суч сного світу. озглянуто дв головні типи вертик льно-структурних процесів: зовнішні т внутрішні. ерші стосуються зміни геополітичного ст тусу держ в, другі - окремих їхніх регіонів. мін ст тусу суттєво вплив є н зд тність держ ви вирішув ти політико-територі льні конфлікти.

лючові слов : політико-територі льний конфлікт, геополітичний ст тус, політико-територільн структур світу, вертик льно-структурні процеси.

ослідження політико-територі льних конфліктів було і є одним з головних з вд нь політичної геогр фії. кр їнськ геогр фія готов 3 методологічного погляду не тільки д птув ти з рубіжні концепції геополітики і політичної геогр фії, які пояснюють чинники і генезу конфліктів, й використовув ти вл сні н пр цюв ння в цьому руслі. и виходимо з тези, що вирішення політико-територі льних конфліктів з лежить від геополітичного ст тусу суб'єктів конфлікту.

жливим попереднім внеском у цю спр ву є теоретико-методологічні положення політичної геогр фії і геополітики, що стосуються проблем геополітичного потенці лу держ в світу, які розкриті в пр цях вітчизняних вчених . блія, . ністрянського, . ценк , . рб рицької, . гров , . уд рьов, т кож з рубіжних геогр фів . олосов , . ироненко, . чв ров , . ткінсон, . л ссм н, . естер , . ревел кіс , . вер, . стл- олтер т ін. опередні дослідження, які розкрив ють ієр рхію в геополітичній структурі світу, предст влені у пр цях кл сиків геополітики . еллен , . удницького, ж. . ккіндер , . усгофер , . п йкмен , т кож суч сних учених - . рон , . жезінського, . угін .

ля ліпшого відобр ження зміни геополітичних ст тусів кр їн ми використ ли понятійно-термінологічну систему . л єв , як відобр ж є головні н прями досліджень суспільно-геогр фічних явищ. я відом логічн систем охоплює територі льноструктурні, компонентно-структурні, вертик льно-структурні т хроноструктурні процеси [5, с. 197].

жливим попереднім внеском у типіз цію політико-геогр фічних процесів є пр ця . клярської “ олітико-геогр фічні процеси в прикордонних р йон х к рп тської і ернівецької обл стей”, де використ но з пропонов ні . л євим територі льно- т компонентно-структурні п р метри процесів, д птов ні для потреб політико-геогр -

(С) ливк ., 2012 
фічного н лізу [3]. ж ль, втор не приділил дост тньо ув ги вертик льно-структурним і хроноструктурним процес м.

ше з вд ння - визн чення особливостей вертик льно-структурних політико-геогр фічних процесів як в жливого предмет дослідження геоконфліктології.

. л євим, вертик льно-структурні процеси м ють прояв стр тифік ції, результ том якої є вертик льн ярусність, зворотним процесом - вирівнюв ння [5, с. 197].

н ш погляд, міжнн родний політико-територі льний конфлікт є боротьбою двох бо декількох суб'єктів міжн родних відносин 3 вл дун д територією, суверенне пр во визн ч ти ї̈ сm тус і використовув ти ресурси, які вон містить.

еополітичний ст тус уч сників конфлікту і с мого спірного політико-територі льного утворення $є$ в жливою х р ктеристикою для оцінки перспективи вирішення проблеми. иходимо з з с дничої тези про те, що чим вищий геополітичний ст тус держ ви, тим більш імовірність вирішення політико-територі льного конфлікту н ії користь.

оширення вл ди однієї держ ви н територію іншої без огляду н суверенні пр в можн розгляд ти як пр гнення здобуття особливого ст тусу н міжн родній рені. к держ в претендує н роль “н ддерж ви”, “великої держ ви”, “держ ви-гегемон ”, “держ ви-прот гоніст” тощо зі зн чним потенці лом міжн родного впливу. р їну, як потр пляє під суверенний вплив сусідньої держ ви, можн тр ктув ти як $з$ лежну, бо ж ч стково суверенну (буферну).

г льноприйнятим є уявлення про кількісні т якісні зміни н політичній к рті світу. ертик льно-структурні процеси н леж ть до якісних змін. они, відповідно, зумовлюють кількісні. осягнення більшого вторитету н міжн родній рені д є змогу окремим держ в м розр ховув ти н лояльність міжн родного співтов риств в р зі вирішення їхніх політико-територі льних проблем. $\quad$ вп ки, його втр т може знизити інтерес i, в ліпшому р зі, з безпечити тільки п сивну підтримку сл бкої держ ви.

еополітичний ст тус кр їни з лежить від т кої його х р ктеристики. як могутність i сил . чв ровим i . уліборським, могутність, силу держ ви н лізують передусім у вз ємозв'язку держ вної вл ди з економічними, політичними і військовими вплив ми держ ви. б л нсув ння сил держ в є в жливим чинником міжн родних відносин. 3 ємини між кр їн ми, з одного боку, свідч ть про дин мічну співпр цю, $з$ іншого, - про ст н зм г ння, конкуренції, як дотичн до т ких х р ктеристик, як впливовість і могутність - економічн , політичн чи військов . ожн держ в дом г ється осягнення ліпшого зовнішнього середовищ, яке необхідне для вл сного розвитку. цього погляду могутність держ в можн оцінити через порівняння з іншими кр їн ми. ерж в є потугою тільки тоді, коли суверенн . лежн чи розділен кр їн не $є$ потужною, н вп ки, вон є джерелом конфліктів і сл бким “вогником” у світовому б л нсі сил [6, с.139].

ідповідно до пропозицій мерик нського геополітик · оен (1997), могутність держ ви повинн бути предметом н лізу з т кими н прям ми: 1) морфологічн зумовленість, як виник є 3 т ких геогр фічних х р ктеристик, як розмір і форм території, т кож геогр фічне положення; 2) демогр фічні особливості - кількість жителів, структур людності, мігр ції, психологічні уст новки, х р ктер н роду тощо; 3) економічні особливості - виплив ють із з собів держ ви, її технологічного розвитку і ч стки в світовій торгівлі; 4) орг ніз ційних особливостей - т к зв ного х р ктеру урядув ння, ст більності й вторитету вл ди; 5) військові передумови - кількість рмії; підготовк і технічн з безпеченість, т кож боєзд тність; 6) зовнішня інтегр ція - вимірюється 
престижем держ ви н міжн родній рені, т кож її роллю в міжн родних орг ніз ціях і союз х [6, с. 139-140].

гідно з методологією озвідув льної р ди , рівень могутності держ ви - це місце в рейтингу, яке визн ч ють 3 сукупним середнім пок зником , витр т ми н оборону, н селення і технології. ей пок зник вир ж ють у відносній (відсотковій) ч стці від з г льносвітової могутності [2, с. 19].

визн ченням “ іжн родної енциклопедії суспільної геогр фії”, сил - це зд тність об'єКт продукув ти вплив, здійснюв ти контроль чи н в'язув ти вторитет іншим особ м чи об'єкт м [7, с. 352].

. роном, сил держ ви може виявлятися: 1) у вигляді потенційної сили - сукупності м тері льних, людських і духовних ресурсів, якими кожне політичне утворення володіє н п пері; 2) у вигляді ре льної сили, тобто ресурсів, які мобілізов ні для пров дження зовнішньої політики в ч си війни і в ч си миру. ч си війни ре льн сил - це м йже те с ме, що військов сил [1].

ількісні т якісні зміни н ведених вище компонентів могутності зумовлюють висхідні і низхідні політико-геогр фічні процеси, які визн ч ють перебув ння тієї чи іншої кр їни в певному геополітичному ст тусі і є причиною вертик льної стр тифік цї̈ політико-територі льної структури суч сного світу. опри форм льну рівність усіх суверенних держ в, як з безпечен норм ми міжн родного пр в , ре льність з свідчує н явність неодн кових потенці лів для вирішення політико-територі льних проблем. е вип дково відомий польський геогр ф . ток визн ч є проблему ре льності суверенітету м лих н ціон льних держ в як одну з основних дослідницьких проблем політичної геогр фії [8]. тже, об'єктивним політико-геогр фічним процесом є ієр pхіз ція геополітичних ст тусів. ї результ т - поляриз ція геополітичних потенці лів. к н слідок, н одному полюсі перебув тимуть держ ви-гегемони, н іншому - недієзд тні держ ви. ля ієр рхіз ції, як процесу, х р ктерний вертик льний рух держ в від одного полюс до іншого. ричому висхідний рух зумовлений і водноч с лімітов ний н зв ними вище скл довими могутності держ ви. огіршення цих пок зників зумовлює втр ту позицій в ієр рхії геополітичної структури світу і, відповідно, зменшує можливості кр їни у врегулюв нні зовнішніх і внутрішніх політико-територі льних конфліктів.

ертик льно-структурні процеси можн розділити н дв типи: держ вний і лок льний. ерж вний рівень передб ч є зміну ст тусу держ ви в міжн родній ієр рхії. томість лок льний зумовлює зміну політико-пр вового ст тусу окремих регіонів кр їни.

ожн н вести б г то прикл дів, коли суперечності між цілями щодо досягнення певного ст тусу кр їною, ре льними внутрішніми можливостями т обст вин ми їі політико-геогр фічного положення можуть спровокув ти конфлікт. прикл д, невд л спроб р ку здобути ст тус регіон льної держ ви з вдяки нексії увейту спричинил конфлікт, який трив є досі. ряд р ку був суворо пок р ний 3 гресію у вигляді с нкцій і міжн родної окуп ції його території. вп ки, втруч ння осії у внутрішні спр ви рузії під ч с війни 2008 р. привело до утворення двох м ріонеткових с мопроголошених держ в - бх зії т івденної сетії. поч тку нег тивн ре кція світу н ці події з ч сом змінил сь н вир зно нейтр льну і н віть нтигрузинську. обто геополітичний ст тус не є н дум ним н уковцями явищем у міжн родних відносин х, ре льною неформ льною х р ктеристикою держ ви. д тність держ ви ефективно і н свою користь використовув ти н бутий геополітичний ст тус у вирішенні зовнішньополітичних проблем, зокрем , і політико-територі льних конфліктів, є свідчен- 
ням їі ре льної в ги у світі. вп ки, незд тність протистояти зовнішньому і внутрішньому тиску у політико-територі льних проблем х $є$ х р ктеристикою геополітично сл бкої, бо жз лежної кр їни.

явність ієр рхії підтверджують ф кти існув ння форм лізов них груп топ-держ в під н зв ми “ елик вісімк”, “ елик дв дцятк” т ін. одн з кр їн цих елітних клубів не готов добровільно чи примусово поступитись своїми політико-територі льними інтерес ми н користь нижчих 3 ієр рхією держ в. томість вони готові сприйм ти дефр гмент цію нижчих з геополітичним ст тусом кр їн під різними привод ми. обто н явність держ в-гегемонів очевидн .

н ш погляд, можн ввести у н уковий ужиток термін держ в -nрот гоніст, як м є обмежені компоненти могутності й регіон льний м сшт б впливу. одібні держ ви у зовнішньополітичній поведінці н слідують держ в-гегемонів. они м ють мбіції щодо уч сті у врегулюв нні проблем т конфліктів н глоб льному рівні, одн к н йефективніше з безпечують вл сні політико-територі льні інтереси в регіоні. о т ких можн з числити р н, удівську р вію, кист н, ольщу з їхніми т к зв ними історичними інтерес ми і пр в ми у прикордонних регіон х суміжних держ в.

ними в світовому рейтингу стоять зн чні регіон льні держ ви з лок льним впливом н політико-територі льні процеси. хніми н йвир знішими компонент ми могутності є зн чн територія і кількість н селення. сі інші скл дові могутності - непропорційно м лі. они ж можуть бути об'єкт ми впливу вищих в ієр рхії держ в, змушені формув ти ко ліції подібних собі держ в для з безпечення вл сної геополітичної рівнов ги. дн к розміри і велик кількість сусідів першого т другого порядків зумовлюють потребу у вирішенні лок льних політико-територі льних проблем. уттєвими чинник ми впливу н сусідні держ ви ст ють зн чн кількість н селення, н явність вл сних ді спор і н ціон льних меншин у суміжних держ в х 3 певних сприятливих обст вин. ля вирішення скл дних політико-територі льних проблем у цих держ в може не вист ч ти т ких компонентів могутності, як боєзд тні збройні сили, політичн консолід ція суспільств т еліт, економічний потенці л. о т ких можемо з числити гипет, івденну фрику, кр їну т ін.

ижчі позиції в світовій ієр рхії з йм ють кр їни з єдиним компонентом могутності, н прикл д, вони виділяються розмір ми збройних сил ( $\quad$ ), природно-ресурсним потенці лом ( ). ожуть приверт ти ув гу світового співтов риств до вл сних політико-територі льних проблем з вдяки гіперрозвинутому однокомпонентному потенці лу. кі кр їни пропонуємо н зив ти кцентов но могутніми. хні політикотериторі льні проблеми приверт ють ув гу світу з огляду н можливість дест білізув ти міжн родні відносини, використовуючи єдиний н явний інструмент сили.

е нижчі з геополітичним ст тусом - буферні держ ви, які тр ктують як нез лежні кр їни, що розміщені поміж потужними $m$ імперськи н $л$ штов ними сусід ми [9, с. 133]. ожн н вести численні історичні прикл ди буферних держ в у - ст.: 1) ельгія, як в -першій половині ст. розмежовув л р нцію і імеччину; 2) орея, як розмежовув л сфери інтересів ит ю т понії; 3) інляндія, як в період холодної війни відігр в л роль буферної держ ви у протистоянні між ходом і ходом; 4) онголія - між і осією; 5) ольщ у міжвоєнний період розмежовув л імеччину і дянський оюз; 6) їл нд ( і м) був буферною держ вою між брит нськими і фр нцузькими колоні льними володіннями у м териковій івденнохідній зії; 7) ез лежний до 1959 р. ибет розмежовув в впливи ндії й ит ю т ін. 
олітико-територі льні проблеми буферної держ ви можуть бути використ ні держ в ми-гегемон ми у вл сних геополітичних інтерес х. роцес створення буферної держ ви, що ініційов ний їі могутнім сусідом і м є відобр ження у з лежній зовнішній і внутрішній політиці, прийнято н зив ти “фінляндиз цією”. зн ки т кої буферної держ ви прит м нні олдові. ор з більше свідчень того, що кр їн втр ч є перев ги зн чної держ ви й опуск ється до ст тусу буферної між $і$, , одного боку, і осією, - $з$ іншого.

кремо виділимо т к зв ні держ ви-с теліти, безпек яких безпосередньо $з$ лежить від договірно-пр вових відносин з могутнішими держ в ми бо ж міждерж вними союз ми. ожливість урегулюв ння зовнішніх політико-територі льних конфліктів повністю з лежить від держ в-гегемонів бо ж колективних рішень т ких міждерж вних союзів як чи . ільшість з них - м лі з площею держ ви із нечисленним н селенням. иповими прикл д ми є б лтійські держ ви під “п р солькою” збройних сил чи джикист н т ірменія, які де-ф кто є військовими протектор т ми осії.

йнижчі позиції з йм ють кр їни, які не м ють жодного компонент, що його можн було $6 з$ числити до компонентів могутності. олітико-територі льні проблеми цих кр їн - це їхня “проблем ” з погляду ре лістичного підходу у міжн родних відносин х. хні вз ємні суперечки не приверт ють ув ги світової гром дськості і, отже, вони перебув ють н периферії світового геоконфліктологічного дискурсу, який формується , диплом т ми, експертними середовищ ми. о цих кр їн н лежить більшість м ловпливових держ в фрики, тинської мерики, зії т ке нії. х сьогодні з числяють до т к зв них недієзд тних держ в ( нгл. failed states). ндекс недієзд тності кр їни - комплексний пок зник, який відобр ж є зд тність держ ви виконув ти свої суверенні функції і з безпечув ти ст лий розвиток у м йбутньому. ндекс розробили онд миру і ред кція журн лу “ овнішня політик” ( ). нжув ння проводять н підст ві суми 12 індик торів. прикл д, ст ном н 2010 р. н йвищий пок зник і н йнижчу ст більність м ли ом лі $(114,3)$, д $(113,3)$, уд н $(111,8)$, імб бве $(110,2)$, емокр тичн еспублік онго $(109,9)$ [4].

евизн ні с мопроголошені кр їни ( урецьк еспублік івнічного іпру,

гірний р б х, ридністровськ олд вськ еспублік ), т кож ч стково визн ні ( йв нь, осово, бх зія) є кв зідерж в ми і невіддільними ч стин ми політико-територі льної структури суч сного світу. вдяки протекції кр їн-гегемонів і кр їн-прот гоністів вони зд тні контролюв ти вл сну територію і проектув ти їхню могутність у p зі вирішення вл сних зовнішніх політико-територі льних проблем. вдяки цьому с мопроголошені невизн ні держ ви ліпше, ніж недієзд тні держ ви, вирішують вл сні політико-територі льні конфлікти з сусід ми.

озглянемо прикл ди вертик льної стр тифік ції н лок льному рівні. езульт том внутрішньодерж вних процесів і зовнішнього впливу можуть бути підвищення бо зниження політико-пр вового ст тусу території, яК є об'єктом політико-територі льного конфлікту. ідвищення ст тусу може м ти т ку логічну послідовність ст нів: дміністр тивно-територі льн одиниця > територі льн втономія > суб'єкт федер ції > суб'єкт конфедер ції > суверенн держ в (с мопроголошен невизн н держ в ). держ в х із з морськими володіннями: колонія > с моврядн колонія (з морський деп рт мент, домініон) > соційов н держ в (протектор т, кондомініум) > суверенн держ в . ниження ст тусу відбув ється у зворотному порядку, н прикл д, у вип дку, коли суверенн орногорія (1878-1918) ст л ч стиною госл вії і відчул н собі 
н слідки центр ліз ції цієї держ ви у міжвоєнний період і децентр ліз ції після ругої світової війни. етроспективний н ліз вертик льно-структурних процесів з свідчує, що підвищення і зниження політико-пр вового ст тусу не обов'язково відбув ється із дотрим нням чіткої послідовності, може м ти стрибкоподібний х р ктер, як у виП дку з втономним кр єм осово і етохія колишньої госл вії, який від ст тусу втономії ербії одр зу ж піднявся в ієр рхії до рівня суверенної держ ви.

кономічний чинник вертик льно-структурних процесів виявляється у ст тусі регіонів-донорів, регіонів-реципієнтів економічної допомоги і суттєво вплив є н деволюційні процеси в кр їні. р гнення б г тих регіонів позбутися н дмірної опіки центр льного уряду в перерозподілі под ткових н дходжень, з одного боку, з іншого, - б ж ння бідних регіонів с мостійно вирішув ти свої проблеми, н прикл д, із з лученням зовнішніх джерел фін нсув ння, можуть привести до децентр ліз ції уніт рних держ в і формув ння регіон льної ідентичності. я ідентичність грунтується не тільки н спільній регіон льній історії і суч сності, передусім вон спрямов н н конструюв ння м йбутнього регіону н з с д х вл сних цінностей т інтересів. еред них можуть бути і пит ння політико-територі льного х р ктеру.

еякі прикордонні, бо ж тр нскордонні історико-геогр фічні регіони можуть м ти геополітичні обр зи, які поляг ють в особливих “історичних пр в х" бо ж політиці регіон льного ірредентизму. прикл д, переселені з території суч сної ольщі лемки, н дсянці і бойки чітко висловлюють свої історичні пр в щодо повернення н свою м лу тьківщину. кі прикордонні регіони, як личин, онб с, рим, к рп ття, лобож нщин , зд тні формув ти вл сні геополітичні проекти тр нскордонного х р ктеру. рихід предст вників регіон льних еліт до вл ди в столиці веде до з гострення, консервув ння бо ж вирішення політико-територі льних конфліктів.

кремі регіони зд тні вплив ти н політику держ ви 3 допомогою ді спор. прикл д, з хідн укр їнськ ді спор , більшість якої є вихідцями із хідної кр їни, досить ефективний інструмент формув ння гром дської думки і лобізму в середовищі політичних еліт кр їни-гегемон - . . г д ємо і зворотний, ч сто деструктивний, 3 погляду кр їни, вплив з кордонних русинських ді спорних груп н політико-геогр фічні процеси в к рп тті, хідній лов ччині, івнічній горщині й окремих регіон х умунії т ольщі.

крім ді спор, регіон може бути об'єктом впливу відкритої чи прихов ної політики суміжних держ в. рикл дом може слугув ти політик підтримки “співвітчизників" боку ольщі, горщини, умунії, осії, зр їлю в регіон х кр їни, де зн чну ч стку в н селенні ст новлять відповідні етнічні групи.

осить відчутним є релігійний чинник. вдяки н явності вир зних конфесійних х р ктеристик регіон може м ти в жливий м ркер с моідентифік ції, н прикл д, “к толицьк в рія”, “протест нтськ ейн- естф лія” у імеччині, чи “греко-к толицьк личин ”, “пр восл вн уковин ”в кр їні.

к б чимо, у більшості кр їн світу можн виділити ієр рхію регіонів не тільки 3 політико-пр вовим ст тусом, як у осії, одноч сно з різним геополітичним ст тусом нез лежно від форми політико-територі льного устрою. еобхідними умов ми привілейов ності регіону будуть: суттєво більш площ і кількість н селення, високий рівень предст вництв у пр влячій еліті, вищий від середнього по кр їні рівень економічного розвитку, н явність регіон льної свідомості, регіон льних міфів месі нського х р ктеру, вир зн релігійн чи конфесійн н лежність, рівень консолід ції місцевих суспільних груп і еліт, н явність впливових ді спор, вплив зовнішніх геополітичних 
центрів сили, н явність суміжних територій, які історично н леж ли до регіону, н явність суч сних бо ж колишніх держ вних політичних центрів.

будь-якій кр їні можн виділити регіони з їхнім ст тусом: 1) геополітично л більні (не м ють чіткої держ вотворчої доцентрової орієнт ції, можуть орієнтув тись н зовнішні геополітичні проекти); 2) геополітично л тентні (не виявляють суттєвих відцентрових чи доцентрових тенденцій); 3) геополітично ктивні (виявляють суттєві доцентрові/відцентрові держ вницькі тенденції). різні історичні періоди регіон може змінюв ти свій ст тус. се це суттєво вплив є н його конфліктний потенці л. йбільше конфліктність генерується у геополітично л більних і геополітично ктивних регіон х держ ви. р йньою формою геополітичної ктивності регіону є формув ння т к зв ної п ртиз нської держ ви - території, контрольов ної повст нськими міліт рними угрупов ннями. одо геополітично л більних регіонів, то вони можуть з зн в ти суттєвого впливу держ в-сусідів і з сприятливих для них обст вин приєдн тись до них.

тже, н ліз вертик льно-структурних політико-геогр фічних процесів доводить, що системі міжн родних відносин прит м нний процес ієр рхіз ції геополітичних ст тусів окремих держ в і їхніх регіонів. ін суттєво вплив $є$ н зд тність держ ви вирішув ти її політико-територі льні конфлікти. од льші дослідження потрібно зосередити н вдоскон ленні типології держ в і регіонів 3 їхнім геополітичним ст тусом.

окрему ув гу з слуговує вивчення хроноструктурних політико-геогр фічних процесів у їхній дотичності до геоконфліктологічної проблем тики.

1. рон . ир і війн міжн ціями / еймон рон. - . : ніверс, 2000. - 684 с.

2. лоб льні зміни світу - 2025. оповідь ціон льної розвідув льної р ди

[ ер. 3 нгл.

их йл ом рницького, есі реховецької, нни елів т ін.]. - ьвів : ітопис, 2010. -188 с.

3. клярськ . олітико-геогр фічні процеси в прикордонних р йон х к рп тської і ернівецької обл стей : моногр фія / кс н клярськ .- ьвів : ьвівський н ціон льний університет імені в н р нК, 2011.-228 с.

4. ливк . . стосув ння індексу недієзд тності держ в у дослідженні конфліктної ситу ції в регіон х орного, ервоного морів т хідного ередземномор'я / ом н досл вович ливк // еогр фія і туризм : н ук. зб. / ед. кол.: .. лійник (відп. ред.) т ін. - . : льтерпрес, 2010. ип. $10 .-$.90-97.

5. опчієв . . успільно-геогр фічні дослідження: методологія, методи, методики : н вч. посібник / лекс ндр ригорович опчієв.- дес : стропринт, 2005. -632 с.

6. Baczwarow M. Kopendium wiedzy geografii politycznej i geopolityce. Terminologia / Martin Baczwarow, Andrzej Suliborski. - Warszawa : Wydawnictwo Naukowe PWN, 2003. - $190 \mathrm{~s}$.

7. Cameron E. Indigeneity / E. Cameron // International Encyclopedia of Human Geography in 12 volumes / [Editors-in-Chief Rob Kitchin, and Nigel Thrift]. - Amsterdam : Elsevier, 2009. - Vol. 4. P. 352-357.

8. Otok S. Geografia Polityczna: Geopolityka - Państwo - Ekopolityka / Stanisław Otok. - Warszawa : Wzdawnictwo Naukowe PWN, 2001. - 202 s.

9. Pástor Z. Sanitný kordón / Zoltán Pástor // Slovník Bezpečnostných Vzịahov / Peter Kulašik, Ján Azud, Ján Bajúsz a kolektiv. - Bratislava : Smaragd pedagogické nakladatel'stvo, 1998. - S. 133.

m ття: н дійшл до редколегї 06.12.2011 прийнят до друку 20.12.2011 


\title{
INFLUENCE OF VERTICAL STRUCTURAL POLITICAL AND GEOGRAPHICAL PROCESSES ON THE WORLD'S GEOCONFLICTOLOGICAL SITUATION
}

\author{
R. Slyvka \\ Vasyl Stefanyk Precarpathian National University, \\ Shevchenka St., 57, UA - 76018 Ivano-Frankivsk, Ukraine, \\ e-mail:nauka@pu.if.ua
}

Investigation of conflicts from the point of view of human geography is a relatively new trend requiring an original methodological base. State's striving to reach a higher geopolitical status is considered to be a regular process resulting in hierarchy organization of political and territorial structure of the modern world. Examples of ascending and descending vertical and structural processes have been provided. Their two major types - internal and external have been discussed. The first pertain the changes of the geopolitical status of states, the second - of some their regions. The change in status is influenced considerably on the ability of the state to solve political and territorial conflicts in its favor as well as the geopolitical activity of separate state regions.

Key words: political and territorial conflicts, geopolitical status, world's political and territorial structure, vertical structural processes.

\section{- лив к}

рик рп тский н цион льный университет им. . теф ник

ул. евченк, 57, в но- $р$ нковск, 76018, кр ин, e-mail:nauka@pu.if.ua

сследов ние конфликтов является относительно новым н учным н пр влением в общественной геогр фии, которое нужд ется в р зр ботке собственной методологической б зы. стремления госуд рств , которое пыт ется достигнуть более высокого геополитического ст тус , p ссм трив ют к к з кономерный процесс, в результ те чего проявляется иер рхиз ция политико-территори льной структуры мир . ссмотрено дв тип вертик льно-структурных процессов: внешние и внутренние. ервые описыв ют изменения геополитического ст тус госуд рств, вторые - отдельных регионов. риобретение иного ст тус существенно влияет н способность госуд рств реш ть политико-территори льные конфликты.

лючевые слов : политико-территори льный конфликт, геополитический ст тус, политикотерритори льн я структур мир, вертик льно-структурные процессы. 